\title{
Consumer Taxes on Alcohol: Is the Wine Sector a Niche Within the Alcoholic Beverages?
}

\section{Paola Corsinovi ${ }^{1}$}

Received: 9 February 2021 / Accepted: 23 February 2021 / Published online: 2 April 2021

(c) The Author(s) 2021

\begin{abstract}
As alcoholic beverages play a significant role in social and economic contexts, the taxation of alcohol and its policy regulations are an inevitably complex matter. This note pays a small tribute to the great contribution made by Anderson (J Wine Econ 15(1):42-70, 2020), with a specific focus on the EU wine sector. This text is far from exhaustive but provides a starting block for a more in-depth analysis into this complex issue. Is wine a niche category within the alcoholic beverages sector? The question is provocative. This may be difficult and complex to answer, but this note provides some "food for thought".
\end{abstract}

Keywords Alcohol $\cdot$ Taxes $\cdot$ Wine policy $\cdot$ Wine regulations

JEL Classification $\mathrm{E} 62 \cdot \mathrm{I} 18 \cdot \mathrm{P} 46 \cdot \mathrm{Q} 13$

\section{Introduction}

Taxes placed on alcoholic beverages vary considerably by the type of product, by country and, in several cases, within countries. Historically, these taxes were introduced with the primary purpose of raising national revenues. Nowadays, governments may introduce taxes on alcohol, alongside other regulations, for a variety of reasons. These include economic motivations (to enhance revenues, to protect domestic markets from foreign competition, to raise producer product prices, to protect domestic producers against "dumping" by foreign companies or governments etc.), social motivations (to regulate consumption and reduce negative consequences for both the person drinking and third parties, including unemployment, family problems, violence, crime, etc.) and political motivations (national interests, lobbying pressures and unrelated trade disputes such as the recent tariffs authorized by

Paola Corsinovi

paola.corsinovi@hs-gm.de

1 Hochschule Geisenheim University, Geisenheim, Germany 
WTO, imposed on EU food products in the US market) ${ }^{1}$ (Anderson 2020; Anderson et al. 2018; Meloni et al. 2019).

Prof. Kym Anderson in his paper "Consumer Taxes on Alcohol: An International Comparison over Time" (2020) provides an exhaustive description and estimation of tax rates from 2008 to 2018 imposed on alcoholic products like wine, beer and spirits, for a wide range of high-and middle-income countries. His publication represents the most updated and comprehensive research available on this topic. The author offers several interesting findings, from highlighting the complexity surrounding the taxation of alcoholic products to, in particular, the heterogeneity in tax rates among countries. The research is based on an analysis of taxes as the ad valorem consumer tax equivalent (CTE) in US dollars per unit of alcohol, and as a percentage of the wholesale pre-tax price at representative price points and alcohol percentages. In addition, the author takes into consideration the various Value-Added (VAT) and Good and Services (GST) tax rate across countries. Data are collected from the European Commission, OECD, World Bank and WTO and national government sources. The methodology is addressed by comparing tax rates and other instruments across countries, and for varying beverages types (pages 43-47). Additionally, the author stipulates that finding and designing optimal policies to reduce the negative health and social consequences of the harmful use of alcohol is far from simple.

This note pays tribute to the great contribution made by Prof. Anderson, with a specific focus on the EU wine sector. This short text is far from exhaustive but provides a starting block for a more in-depth analysis into this complex issue.

\section{Consumer Taxes on Wine: "An International Comparison"}

In recent years, the volume of alcohol consumption has increased worldwide. Anderson et al. (2018) show that consumption has increased by one quarter between 2001 and 2015. The World Health Organization (WHO) has estimated that 2.3 billion people are currently drinkers. Alcohol is consumed by more than half of the population within the Americas, Europe and the Western Pacific. It is estimated that $45 \%$ of total recorded alcohol consumed worldwide is in the form of spirits. Beer is the second most common alcoholic beverage (34\%) followed by wine (12\%) (WHO 2018). ${ }^{2}$

The wine sector therefore makes up an important part of total alcohol consumption. Especially in the European Union, where the EU comes first in terms of producers and consumers, and is the primary exporter and importer of wine in the world. The EU accounts for $44 \%$ of the world's wine growing areas (with also 2.5

\footnotetext{
${ }^{1}$ In October 2019, the US was authorized to impose additional duties (on approximately $\$ 7.5$ billion) on EU products as a result of the WTO Airbus case. The USA imposed tariffs of $25 \%$ on many food products such as wine, cheese and olive oil. In September 2020 the EU was authorized to impose tariffs affecting $\$ 4$ billion in US trade as a result of related WTO disputes (https://ec.europa.eu/commission/ presscorner/detail/en/ip_20_2048).

${ }^{2}$ https://www.who.int/news/item/21-09-2018-harmful-use-of-alcohol-kills-more-than-3-million-peopl e-each-year--most-of-them-men.
} 
million wine growers), $61 \%$ of total production (Spain, France and Italy account for $76 \%$ of EU areas under vines), $53 \%$ of global wine consumption and $67 \%$ of the total exports (OIV 2019) Close to 15\% of EU domestically produced wine is exported to non-EU countries (wine is the most exported EU agri-food product, accounting for $€ 12.1$ billion in 2019), while about $30 \%$ of it is traded on the EU market (EU Commission 2019). According to International Organisation of Vine and Wine (OIV) 2019, world wine consumption is estimated at 246 million hectoliters. The biggest consumers, USA (33 Mhl), France (26 Mhl), Italy (22.4 Mhl), Germany (20 Mhl) and China (18 Mhl), together represent half of total world consumption (49\%). However, due to health concerns, changing consumption patterns and cultural dimensions the EU's annual per capita wine consumption is decreasing. By contrast the demand for wine has increased rapidly outside EU like in the United States and non-traditional producing countries like in China, the UK, Russia, and Canada (EU Commission 2019, 20203 ; OIV 2019).

As alcoholic beverages play a significant role in social and economic contexts, the taxation of alcohol and its policy regulations are an inevitably complex matter. This is especially the case when compared at the international level. According to Anderson (2020), comparing the excise taxes on wine, beer and spirits from 2008 to 2018 across 42 countries, wine is taxed slightly less than beer and spirits, although taxes for all three products have risen during the period studied. As a percentage of the pre-tax wholesale price, wine taxes averaged at $22 \%$, beer at $29 \%$ and spirits at $75 \%$. As US\$ per liter of alcohol wine taxes averaged to $11.4 \$$ compared to beer at $14.0 \$$ and spirits at $24.7 \$$. Further, when excise taxes were added to import taxes and the value-added tax imposed by many countries, "the combined taxes averaged around 50\% for wine and beer in 2008 and 60\% in 2018, and around twice that for spirits" (Anderson 2020, pg. 49).

Countries can apply tariffs on wine according to various aspects: (a) ad valorem (according to the price of the wine); (b) volume based; (c) alcohol contents (per liter of alcohol in the product); or (d) typologies (such as still, sparkling, bottled and bulk). Depending on the importing countries, a tariff applied on a bottle of wine differs on the nominal duty and instruments used (Mariani and Pomarici 2019). Specific tariffs based on volume are the most popular in EU countries and the US, whilst tariffs based on value are more popular in $\mathrm{Asia}^{4}$ (Anderson 2010).

The EU wine export sector has an especially varied and complex tariff system. These values are published in the Official Journal of the EU. Within the EU, Member States have created a minimum common framework to regulate aspects of general interest, leaving national interests up to individual national legislations in line with the principle of subsidiarity. In addition to wine, other fermented drinks, intermediate alcoholic products and ethyl alcohol are also subject to excise duties if produced in processing facilities managed under the fiscal warehousing scheme (Gaeta

\footnotetext{
${ }^{3}$ DG AGRI forecast that the volume of wine consumed in Europe is expected to reach 25lt per capita by 2030 ( $-0.4 \%$ per year).

${ }^{4}$ However, countries who have signed the Free Trade Agreements can import/export at special conditions and tariff rates.
} 
and Corsinovi 2014). In the EU, excise duties for alcohol are regulated through two main directives. First, there the directive n. 92/83/EEC, defining the structure of excise duties, the categories of products they apply to and the basis on which they are calculated. ${ }^{5}$ Second, there is directive 92/84/EEC setting out harmonized minimum rates for each category of products, above which Member States are free to fix their own rates according to their needs. The minimum rate imposed for wine and sparkling wine is currently zero, while intermediate products (e.g. liqueur wines) face a $45 €$ excise duty per hectoliter. ${ }^{6}$ Alcohol and alcoholic beverages are also subject to the common provisions for excise goods under EU law set out in Directive 2008/118/EC, which covers the general excise duty scheme and established a general regime for goods subject to excise duties between Member States. ${ }^{7}$

Anderson (2020), taking into consideration 42 countries (from Argentina to United States), shows great disparities in tax rates, especially among traditionally consuming countries, traditionally producer countries and Northwestern European countries. The traditionally wine-focused countries (both in terms of supply and demand) including Germany, Italy, the United States and Argentina have amongst the lowest taxes. In 2019, the USA, top consumer and the primary market destination for EU wines (outside EU), registered a notable increase in the importation of wine with respect to 2018 , both in the volume imported (+7.1\%) reaching $12.3 \mathrm{Mhl}$, and in value $(+5.7 \%)$ reaching $€ 5.5$ billion (OIV 2019). Anderson (2020) furthermore shows huge differences in the tax rates on sparkling versus still wines, as well as huge differences in the types of taxes introduced. Specifically, four countries taxed their wine consumers with an ad valorem tax in 2018: Chile (20.5\%), Mexico (26.5\%), Australia (29\%), and Korea (33\%) with a Consumer Tax Equivalent (CET) in terms of dollars per liter of alcohol, and hence per bottle very high for superpremium still and sparkling wines (Tables A1-A2-A3 pages 62-64).

Moreover, the analysis of VAT/GST Rate, 2008/2018 draws the different contributions, which the Member States make towards supporting consumption, or at least not penalizing it. Europe sets the broad VAT rules through European VAT Directive n.2006/112/EC. ${ }^{8}$ Focusing on Europe's main wine-producing countries, the paper shows that VAT stands at $20 \%$ in France and $22 \%$ in Italy. Similarly, these fall at $19 \%$ in Germany, $21 \%$ in Spain and $13 \%$ in Portugal (but $23 \%$ for sparkling wines). Conversely, Northern European countries again face higher rates at 24\% in Finland and $25 \%$ in Sweden, Denmark and Iceland. Hungary places the highest VAT at $27 \%$. The EU VAT Directive sets the framework for the VAT rates in the EU, but provides certain freedoms to national governments to set the levels of these rates, subject to two basic rules: (1) the standard rate for all goods and services: the standard rate of VAT to be applied by all EU countries to goods and services is at least $15 \%$. EU countries may apply one or two reduced rates of at least $5 \%$ to specific goods or

\footnotetext{
5 https://eur-lex.europa.eu/summary/EN/131023.

${ }^{6}$ https://ec.europa.eu/taxation_customs/business/excise-duties-alcohol-tobacco-energy/excise-dutie s-alcohol_en.

7 https://eur-lex.europa.eu/legal-content/EN/TXT/?uri=CELEX\%3A02008L0118-20200101.

8 https://eur-lex.europa.eu/legal-content/EN/TXT/PDF/?uri=CELEX:32006L0112\&from=IT.
} 
services listed in Annex III of the directive. (2) A EU country can opt to apply one or two reduced rates but only to goods or services listed in the VAT Directive. ${ }^{9}$

Finally, Anderson (2020) shows the correlation between wine's share of alcohol consumption volume and the average tax on wine (\$) per liter of alcohol and the percentage of wine types in total volume of wine consumption at 2009 for the categories non premium, commercial premium, super premium and sparkling. Considering the correlation between production and consumption the study shows a negative relationship between wine taxes and the share of wine in alcohol consumption.

The key question that remains is what is the best tax rate? Anderson (2020) remarks that taxation imposed according to a product's perceived value "(ad valorem) is not likely to be the first-best tax instrument" (pg. 59). Ad valorem taxes could encourage the consumption of low priced wines, increasing negative externalities rather than reduce it and from a market perspective "also encourages (discourages) exports of premium (non- premium) wines from such countries and has the opposite impacts on wine imports (pg. 59)".

\section{Is the Wine Sector a Niche Within the Alcoholic Beverages Category? Some "Food for Thought"}

Anderson (2020) has shown how wine rates have risen mainly in non-wine-producing countries and how the main historical wine countries have the lowest tax rates with respect to beer and even more so compared to spirits. The author concludes that even if health lobbyists have required high taxes on alcohol consumption in addition to other policy regulations "evidently, the industry counter-lobbying has been uneven and/or has been successful in making the case that wine consumption is generally less harmful than other alcohol consumption" (pg. 59).

Therefore, is wine a niche category within the alcoholic beverages sector?

Firstly, the harmonization of fiscal tariffs in the EU is a complicated issue. Any change or community harmonization, such as excise taxes, requires unanimous agreement and it will, therefore, always be very difficult for the Member States to reach an agreement on these rates (Gaeta and Corsinovi 2014). Secondly, the dynamic growth of wine traded outside the EU, and the development of many Free Trade Agreements (FTAs) have contributed to the progressive reduction of many tariffs in the wine sector. By contrast, there has been a growing use of non- tariff instruments such as the Sanitary and Phytosanitary Measures, including the tolerance limits for residues, restricted use of substances, labelling requirements related to food safety, standards of shipments and certification requirements which contributed to generates additional frictions to trade and increase costs of imports (Corsinovi and Gaeta 2017, 2019).

Thirdly, the WHO has played an important role over the years emphasizing that "an increase in excise taxes on alcoholic beverages is a proven measure to reduce

\footnotetext{
9 https://ec.europa.eu/taxation_customs/business/vat/eu-vat-rules-topic/vat-rates_en and Council Directive 2006/112/EC of 28 November 2006 on the common system of value added tax.
} 
harmful use of alcohol and it provides governments revenue to offset the economic costs of harmful use of alcohol (...)". ${ }^{10}$ It has identified that "the most cost-effective actions to reduce the use of alcohol include taxes on alcoholic beverages, enforcing restrictions on exposure to alcohol advertising, and restrictions on the physical availability of retailed alcohol (...)"11 (see also WHO 2018). Europe's approach to alcohol-related policies is mainly focused on preventative action ${ }^{12}$ : EU is also entitled to adopt measures aimed at ensuring human health protection, including measures to protect public health from alcohol abuse. ${ }^{13}$ Among the EU Member States several measures are introduced to regulate sales, purchasing, consumption and marketing/advertisement of alcoholic beverages ${ }^{14}$ (Anderson et. al 2018; European Commission Joint Research Centre 2020; WHO 2020). In 2006, the EU Commission adopted the EU strategy to support Member States in reducing alcohol-related harm, ${ }^{15}$ which led to the creation of the European Alcohol and Health Forum (EAHF). ${ }^{16}$ Since 2007 many institutions and producer organizations underwent sensibilization campaigns, which included information on responsible wine consumption as well as dangerous behaviors related to alcohol (e.g. binge-drinking, driving a car after drinking alcohol, etc.). ${ }^{17}$

Finally, a fourth "food for thought" element emerges. The EU does not support the production of spirit drinks but provides for a common legislative framework as regards their production and labelling and the protection of geographical indications with Regulations 110/2008 and 716/2013. At the EU level there are 47 spirit drink categories regulated (e.g. rum, whisky, brandy) and the approximately 240 geographical indications (e.g. Madeira Rum, Scotch Whiskey, Cognac, Grappa). ${ }^{18}$ On the one hand EU wine policy has preserved its uniqueness over the time: the Common Agriculture Policy (CAP) allocates almost $€ 6.242$ billion (the period 2019-2023) to the quality and competitiveness of EU wine sector through the instruments included in the National Support Programmes provided by the Common Market Organisation (CMO) with Reg. $1308 / 2013$. On the other hand, to comply with the opposition of the Directorate General for Health and Food Safety of the European Commission (DG SANTE), as well as many health lobbies, the Directorate General of Agriculture (DG AGRI) and the wine lobbies, had to reach various compromises. Among these, for examples, within the National Support Programme the measure "Promotion" which covers almost 20\%

\footnotetext{
$\overline{10}$ https://www.who.int/substance_abuse/safer/r/en/.

11 https://www.who.int/health-topics/alcohol\#tab=tab_3.

12 EU has introduced the "European action plan to reduce the harmful use of alcohol 2012-2020" https ://www.euro.who.int/_data/assets/pdf_file/0008/178163/E96726.pdf.

13 Consolidated version of the Treaty on the Functioning of EU, Part Three: Union Policies and Internal Actions-Title XIV, Public Health art.168.

14 For example, in Italy art. 13 of Law No. 125/2001 on alcohol and alcohol-related problems, regulates alcohol advertising, such as a ban on advertising during children's programmes on TV and radio and in cinemas. https://eucam.info/regulations-on-alcohol-marketing/italy/.

15 https://eur-lex.europa.eu/legal-content/EN/TXT/?uri=CELEX\%3A52006DC0625.

16 https://ec.europa.eu/health/alcohol/overview_en.

17 Such us the EU programme called "Wine in Moderation" (https://www.wineinmoderation.eu/).

18 https://ec.europa.eu/info/food-farming-fisheries/plants-and-plant-products/plant-products/spirits_en.
} 
of the budgets ( $€ 1.132$ billion between 2019 and 2023) has today different approaches of implementation. More specifically, only in countries outside the EU is possible to develop competitiveness based on promotion campaigns such as the participation at events or exhibitions, advertisement, tasting, public relation (etc.) (Promotion in third countries), while in the EU only information on responsible consumption and about the EU quality systems of PDO and PGI are allowed (Pomarici and Sardone 2020). Thus these highly resemble horizontal Regulation $1144 / 2014^{19}$ which provides rules for information provision and promotion measures for agricultural products implemented in the internal market and in non-EU countries which may be fully or partially financed by the EU budget (EU Commission 2020).

The question remains, how long will the wine sector (and related policies) be able to differentiate themselves from other alcoholic beverages?

Funding Open Access funding enabled and organized by Projekt DEAL.

Open Access This article is licensed under a Creative Commons Attribution 4.0 International License, which permits use, sharing, adaptation, distribution and reproduction in any medium or format, as long as you give appropriate credit to the original author(s) and the source, provide a link to the Creative Commons licence, and indicate if changes were made. The images or other third party material in this article are included in the article's Creative Commons licence, unless indicated otherwise in a credit line to the material. If material is not included in the article's Creative Commons licence and your intended use is not permitted by statutory regulation or exceeds the permitted use, you will need to obtain permission directly from the copyright holder. To view a copy of this licence, visit http://creativecommons.org/ licenses/by/4.0/.

\section{References}

Anderson K (2010) Excise and import taxes on wine versus beer and spirits: an international comparison. Econ Pap 29(2):215-228. https://doi.org/10.1111/j.1759-3441.2010.00064.x

Anderson K (2020) Consumer taxes on alcohol: an international comparison over time. J Wine Econ 15(1):42-70. https://doi.org/10.1017/jwe.2020.2

Anderson K, Meloni G, Swinnen J (2018) Global alcohol markets: evolving consumption patterns, regulations and industrial organizations. Annu Rev Resour Econ 10:105-132. https://doi.org/10.1146/annur ev-resource-100517-023331

Corsinovi P, Gaeta D (2019) The European wine policies: regulations and strategies. In: Ugaglia AA, Cardebat JM, Corsi A (eds) The Palgrave handbook of wine industry economics, pp 265-290

Corsinovi P, Gaeta D (2017) European wine policies and their consequences on the global wine trade. Econ Agroalimentare Food Econ 19(1):59-88. https://doi.org/10.3280/ECAG2017-001004

European Commission (2019) EU Agricultural outlook for markets and income, 2019-2030. European Commission, DG Agriculture and Rural Development, Brussels. https://ec.europa.eu/info/sites/info/files/ food-farming-fisheries/farming/documents/agricultural-outlook-2019-report_en.pdf

European Commission (2020) Commission staff working document. Evaluation of the cap measures applicable to the wine sector. SWD (2020) 232 final. https://ec.europa.eu/info/sites/info/files/food-farmingfisheries/key_policies/documents/swd2020-232-evaluation-wine-sector_en.pdf

European Commission Joint Research Centre (2020) Alcoholic beverages. https://ec.europa.eu/jrc/en/healt h-knowledge-gateway/promotion-prevention/alcohol

Gaeta D, Corsinovi P (2014) Economics, governance, and politics in the wine market: European union developments. Palgrave Macmillan, London and New York

${ }_{19}$ https://eur-lex.europa.eu/legal-content/EN/TXT/PDF/?uri=CELEX:32014R1144\&from=en. 
Mariani A, Pomarici E (2019) Barriers to wine trade. The Palgrave Handbook of Wine Industry Economics. In: Ugaglia AA, Cardebat JM, Corsi A (eds) The Palgrave handbook of wine industry economics, pp 291-315

Meloni G, Anderson K, Deconinck K, Swinnen J (2019) Wine regulations. Appl Econ Perspect Policy 41(4):620-649. https://doi.org/10.1093/aepp/ppz025

OIV (2019) Statistical Report of World Viticulture. http://oiv.int/public/medias/6782/oiv-2019-statistica 1-report-on-world-vitiviniculture.pdf

Pomarici E, Sardone R (2020) EU wine policy in the framework of the CAP: post-2020 challenges. Agric Food Econ 8(17):2-40. https://doi.org/10.1186/s40100-020-00159-Z

World Health Organization, WHO (2018), Global Status Report on Alcohol and Health. Geneva: WHO https ://www.who.int/substance_abuse/publications/global_alcohol_report/en/

World Health Organization, WHO (2020), Who Alcohol Marketing in the WHO European Region Update Report On The Evidence And Recommended Policy Actions, WHO Regional Office for Europe https ://apps.who.int/iris/bitstream/handle/10665/336178/WHO-EURO-2020-1266-41016-55678-eng. pdf? sequence $=1 \&$ isAllowed $=\mathrm{y}$ 